\title{
RPAS IN THE SUPPORT FOR PHOTOGRAMMETRY EDUCATION: CASES IN TOPOGRAPHIC MAPPING AND DOCUMENTATION OF HISTORICAL MONUMENTS
}

\author{
M. L. L. Reiss ${ }^{1}$, T. S. G. Mendes 4 , M. R. M. de Andrade ${ }^{5}$, A. de M. Amory ${ }^{3}$, R. de Lara², S. F. de Souza² \\ ${ }^{1}$ LAFOTO - Laboratory of Photogrammetry Research, Department of Geodesy, Institute of Geoscience, UFRGS - Federal \\ University of Rio Grande do Sul, Brazil - (mario.reiss, lafoto) @ufrgs.br \\ ${ }^{2}$ LAGEO - Laboratory of Geodesy, Department of Geodesy, Institute of Geoscience, UFRGS - Federal University of Rio Grande do \\ Sul, Brazil - (rooseveltdelara, sergio.florencia)@ufrgs.br \\ ${ }^{3}$ Faculty of Computer Science, PUCRS - Pontifical Catholic University of Rio Grande do Sul, Brazil - alexandre.amory@pucrs.br \\ ${ }^{4}$ Department of Environmental Engineering, Institute of Science and Technology - ICT, University of São Paulo - UNESP, São José \\ dos Campos, São Paulo, Brazil - tatiana.mendes@unesp.br \\ ${ }^{5}$ National Center for Monitoring and Early Warning of Natural Disasters - CEMADEN, São José dos Campos, São Paulo, Brazil - \\ marcio.andrade@cemaden.gov.br
}

\section{Commission I, ICWG I/II}

KEY WORDS: Photogrammetry, Teaching, RPAS, UAV, Topographic Mapping, Historical Monuments, Environmental Disaster, Risk Areas

\begin{abstract}
:
Currently on the world market there are several models and manufacturers of RPAS-UAV. This equipment made it possible to complete the entire flow of the photogrammetric mapping process in teaching for the students of the Cartographic Engineering course. In the Institute of Geosciences, this course already counted on the photogrammetric stations, equipped with hardware for 3D visualization (graphic card, high-speed monitors and stereoscopic vision glasses), photogrammetric software for data processing, and equipment for geodetic measurement control points. Before the acquisition of the RPAS, for the accomplishment of the academic works, it was necessary to buy or to look for in donations from companies of aerial photographs, that did not always correspond to an area of scientific interest. In addition, the scenes in the photos were not current, and it was impossible to have control points that were pre-signalized. From the availability of the RPAS in the University, the students began to have more interest by Photogrammetry in their professional end of coursework and throughout the disciplines. It became possible to carry out in practice all the processes involved in the mapping of nearby areas of interest, from the planning to the generation of photogrammetric products, such as the generation of DTM (Digital Terrain Model), DEM (Digital Elevation Model), orthophotomaps and extraction of features. In addition to products related to the 3D mapping of terrains, mainly through the RPAS of rotating wings, there was also the possibility of mapping and reconstructing 3D structures, such as buildings of historical monuments.
\end{abstract}

\section{INTRODUCTION}

\subsection{A brief recent history of Cartographic Engineering and Photogrammetry}

In this article we will present how the Federal University of Rio Grande do Sul (UFRGS) has access to some current technologies for the acquisition of geospatial data, emphasizing RPAS; we will show a research done with the help of the UFRGS digital repository, to evaluate the importance of Photogrammetry as an area and theme of the academic and research works; and we will present some papers and their results, performed at the undergraduate level, and how the RPAS influenced teaching, facilitating the accomplishment of complete photogrammetry mapping projects.

UFRGS has a bachelor's degree in Cartographic Engineering since 1998 (soon, in a curricular restructuring, the course will be called Cartographic and Surveying Engineering, Engenharia Cartográfica e de Agrimensura). This course is in the Institute of Geosciences of this University, in which the main department that provides teachers, to assist the specifics of this course, is the Department of Geodesy, which is also part of the same Institute. In addition, it is in the Department of Geodesy that the main resources of laboratories and equipment that attend the Cartographic Engineering of UFRGS, both in relation to research and teaching. Part of the history of this course can be found in 10 Years ... (2007).

Despite its previous foundation, and of having at the time Cartographer Engineers (Geodesists) to assist the demands of Topography, Cartography and Geodesy of other pre-existing courses, it was only from 2005 that new professionals were contracted to attend the demands of Cartographic Engineering. In 2007, federal funding, through a universal project of CNPQ, contemplated a research proposal in the area of Photogrammetry for the development of a system for 3D reconstruction of objects by structured light (Reiss et al., 2009; Reiss and Tommaselli, 2011). With this funding, it was possible to acquire a pair of cameras, a multimedia projector (to project structured light patterns) and a set of computers. All this equipment, besides being used in the research, made possible the creation of the Photogrammetry Research Laboratory at UFRGS (LAFOTO). LAFOTO also provides support in the development of teaching, through assistance in the performance of professional work, which results in the monographs of end of coursework. 
In 2009 and 2010, a National project published by the Federal Government in 2007, aimed at the restructuring of Federal public universities, called the REUNI Project, began to take effect in UFRGS. This project had the specific objective of increasing slots for students in universities and, on the other hand, restructuring its resources through infrastructure improvement, the hiring of professors and the acquisition of technological equipment, through the submission of proposals. Until then, the Topography classes had few and old total stations of various brands (which made it difficult for classes with large students); and Geodesy classes with only a couple of GNSS receivers (GPS only, brand ProMark 2), single frequency and a single analogue gravimeter. For the Photogrammetry area there were in 2005 analogical equipment of the 1960s (mirror stereoscopes, parallax bars) and other old materials, such as old analog metric photographs; in the Department of Geography, in the Antarctic and Climatic Research Nucleus (NUPAC), with limited access to few researchers and students linked to the research developed there was a Digital Photogrammetric Workstation (DPW), composed of hardware with a 3D vision system and LPS software - Leica Photogrammetric Suite.

Thus, in 2009, with a LAFOTO desktop computer equipped with a demo version of the LPS software, 45 aerial photographs of an area near Porto Alegre (acquired with the system SAAPI (Ruy et al., 2012; Ruy et al, 2010, Ruy et al., 2007) from the Engemap company, cordially disposed of the UFRGS), the GNSS receivers and the total stations available in the Department of Geodesy, a work of end course, for photogrammetric mapping of the area of study involved (Klein et al, 2009).

In 2010, the first technological resources began to be purchased through REUNI: a DPW (10 licenses of the LPS software, a computer with a dedicated video card and a 3D vision system of the company Planar based on polarization of the light and semisilver mirror), a pair of Topcon GR3 (GPS and GLONASS) dual frequency GNSS receivers and a Topcon 7505 total station, the technical end of coursework developed in 2009 was repeated by a new team of students (Lima et al, 2010).

In practical terms considering terrestrial Photogrammetry, in view of these new resources acquired in 2010 and the cameras in 2007 , it was already possible to teach and process, the entire flow of the photogrammetric process. However, considering Aerophotogrammetry, the capture step of aerial photographs was lacking (item 3 highlighted in Figure 1).

However, with the resources previously available, in 2010 a partnership between the Porto Alegre City Hall (PMPA) and UFRGS was possible for the university to assist them in the quality control of a municipal mapping project, involving: LIDAR survey; conventional aerial photogrammetric survey (ADS 40 camera) and the cadastral update of urban properties (Zanardi et al, 2013, Zanardi et al, 2014). However, in relation to teaching, it was not possible to acquire aerial images of areas of interest. In order to complete the flow of the aerial photogrammetric process (Fig 1), from 2011, we began (in LAFOTO) to study the feasibility of developing remotely piloted aerial systems (RPAS) to take photographic sensors, thus allowing us to acquire our own photos. At the same time, we sought to study the commercial RPAS that were emerging in the market. A fixed-wing RPAS with a great development of automation for the time, and of considerable low cost, denominated Swinglet CAM, of the company Sensefly was called to the attention to us.

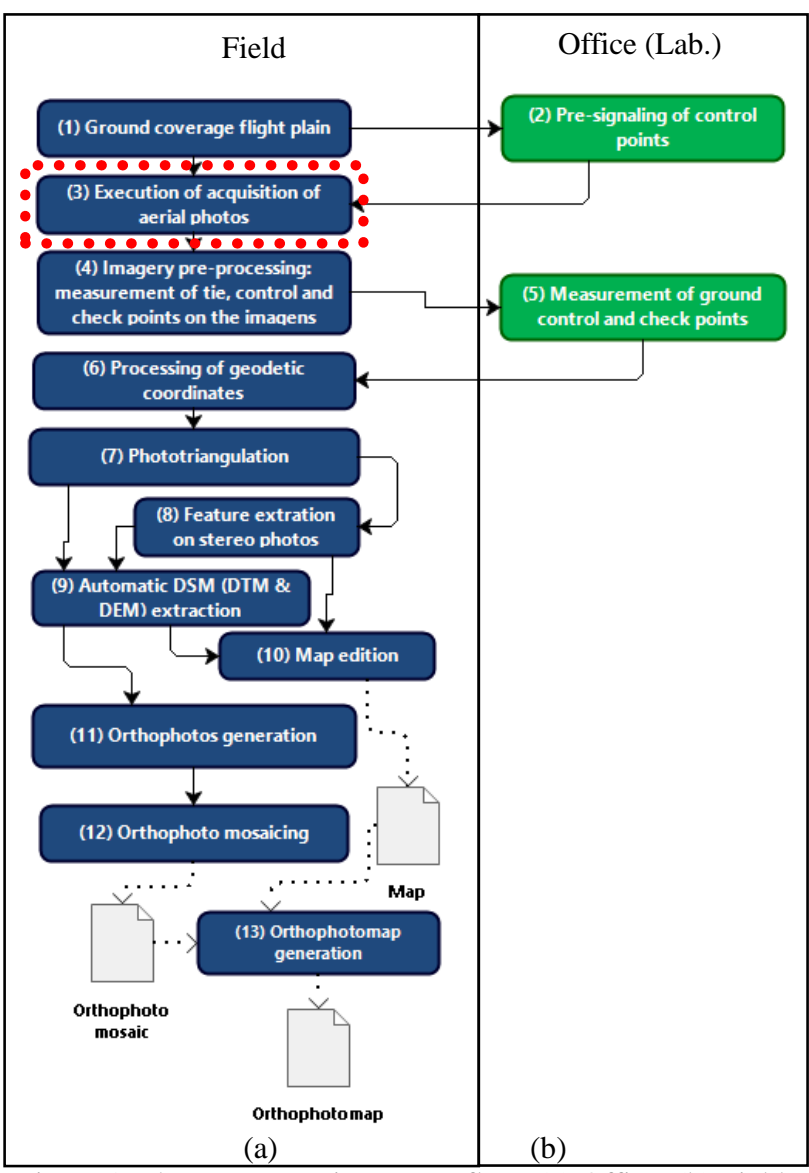

Figure 1. Photogrammetric process flow: (a) Office; (b) Field In highlight the step that was not possible to execute without RPAS in teaching

In a new phase of the REUNI Project, as of 2011, it allowed us to submit new proposals for equipment acquisition. The effects came from 2012, with purchase of the first RPAS Swinglet CAM by a Brazilian University (information according to the only commercial representative of Sensefly in Brazil, the company Santiago \& Cintra). In 2014 we acquired another fixed-wing RPAS, the Sensefly eBee model equipment, and in 2015 the rotary-wing RPAS Ascending Falcon 8 model (now brand belongs to IBM) (Fig 7). This three equipment were first acquired by Universities in Brazil. In addition, in 2014 it was possible to acquire, with own resources of LAFOTO, educational versions of the Agisoft Photoscan Pro software (currently Agisoft Metashape Pro), and with other resources from REUNI, updates of the previous 10 and 10 new licenses up to the 2015 versions of the LPS software (under the new name ERDAS IMAGINE Photogrammetry of the company Hexagon Geospatial); the total of licenses available at the University became 20 . Also, with projects submitted to REUNI we acquired $15 \mathrm{DPW}$ with $3 \mathrm{D}$ vision system based on video cards and nVidia 3D glasses. It was also possible to have a Pix4D software license available (included with the eBee device).

Also, to meet the teaching needs directly related to Photogrammetry, another proposal for the purchase of equipment was submitted to REUNI, having been accepted: a Faro Focus S120 terrestrial laser scanning system (TLS). In addition to this equipment mentioned above, others of great importance were possible to be acquired with the REUNI Project, to attend other demands of the teaching carried out by the Department of Geodesy. They are not specific to the area of 
Photogrammetry but are necessary and important for the development of projects also in Photogrammetry. Tables 1 and 2 below list all resources acquired as of 2005 .

\begin{tabular}{|c|c|c|}
\hline Technological Recourses & Source & Year \\
\hline $\begin{array}{l}10 \text { educational licenses of the } \\
\text { IMAGINE LPS software (version up to } \\
\text { 2011) }\end{array}$ & REUNI & 2010 \\
\hline $\begin{array}{l}1 \mathrm{DPW} \text { (Quadro FX } 4600 \text { video card } \\
\text { and nVidia brand 3D Vision } 2 \text { glasses) }\end{array}$ & REUNI & 2010 \\
\hline $\begin{array}{l}1 \text { fixed wings RPAS of the } \\
\text { Parrot/SenseFly brand, Swinglet CAM } \\
\text { model }\end{array}$ & REUNI & 2013 \\
\hline $\begin{array}{l}\text { 1 DPW (Quadro } 4000 \text { video card and } \\
\text { nVidia 3D Vision } 2 \text { glasses) }\end{array}$ & $\begin{array}{l}\text { REITORIA/ } \\
\text { LAFOTO }\end{array}$ & 2013 \\
\hline $\begin{array}{l}10 \text { educational licenses of the } \\
\text { IMAGINE LPS software (version up to } \\
\text { 2015) }\end{array}$ & REUNI & 2013 \\
\hline $\begin{array}{l}11 \text { educational licenses of the Agisoft } \\
\text { Photoscan Pro software }\end{array}$ & $\begin{array}{l}\text { REITORIA/ } \\
\text { LAFOTO }\end{array}$ & 2014 \\
\hline $\begin{array}{l}15 \text { educational licenses of the INPHO } \\
\text { software }\end{array}$ & $\begin{array}{l}\text { REITORIA/ } \\
\text { LAFOTO }\end{array}$ & 2014 \\
\hline $\begin{array}{l}\text { Didactic Laboratory with } 15 \text { DPW } \\
\text { (Quadro } 4000 \text { video card and nVidia } \\
\text { 3D Vision } 2 \text { glasses) and tables }\end{array}$ & REUNI & 2015 \\
\hline $\begin{array}{l}1 \text { fixed wings RPAS of the } \\
\text { Parrot/SenseFly brand, eBee model }\end{array}$ & REUNI & 2015 \\
\hline $\begin{array}{l}1 \text { rotary wings RPAS of the } \\
\text { Ascending/Intel, model Falcon } 8\end{array}$ & REUNI & 2015 \\
\hline $\begin{array}{l}1 \text { TLS of the Faro brand, Focus S } 120 \\
\text { model }\end{array}$ & REUNI & 2015 \\
\hline
\end{tabular}

Table 1. Technological resources acquired for the area of Photogrammetry

\begin{tabular}{|l|l|l|}
\hline \multicolumn{1}{|c|}{ Technological Recourses } & Source & Year \\
\hline 1 Topcon 7505 total Station & REUNI & 2009 \\
\hline 1 Pair of Topcon GR3 GNSS receivers & REUNI & 2009 \\
\hline $\begin{array}{l}\text { 2 Pairs of Topcon Hiper Lite GNSS } \\
\text { receivers }\end{array}$ & REUNI & 2010 \\
\hline 1 Topcon 7505 total Station & REUNI & 2010 \\
\hline $\begin{array}{l}\text { 1 TLS of the Optec brand, ILRHS HD } \\
\text { model }\end{array}$ & $\begin{array}{c}\text { REITORIA/ } \\
\text { REUNI }\end{array}$ & 2011 \\
\hline
\end{tabular}

Table 2. Technological Resources acquired for other areas of Cartographic Engineering.

With all these resources we had the possibility to carry out complete works involving all phases of the photogrammetric process, from the planning of the photogrammetric coverage, to the production of orthophotomaps. We introduce in our course, beyond the theoretical lessons, field classes with practical activities, for the following procedures:

- Pre-signaling of control points;

- Flight for the acquisition of photographs; and

- Measurement of control points on the ground with techniques of geodetic surveys.

We now have the possibility to choose the area of interest to be mapped. Before, it was only possible to carry out the photogrammetric procedures in areas already photographed by companies that gave us the photos, which were, for the most part, outdated. As the areas were also much larger, the time required to carry out the work was greater. In theoretical and mathematical terms, there is no decrease in the knowledge about processing photos of conventional photogrammetric flights in relation to flights with RPAS. The variations that exist may even be more clearly evidenced in class. We may even say that in some ways, the problems of a flight with RPAS help to better understand and fix the characteristics of conventional flights. There are situations in which flights with RPAS demand close range photographic acquisitions, and with this, there is a need to consider in the coverage plan the concepts that can be neglected in long range flights, such as: depth of field, hyperfocal distance, image distance, Gaussian focal, among others.

In addition to integrating the teaching classes of Photogrammetry, the RPAS were widely used in the end of coursework of the Cartographic Engineering, a teaching activity, which has a mandatory character, but whose subject is freely chosen by students. Some of these works will be described below.

\section{WORKS USING PHOTOGRAMMETRY AND RPAS}

\subsection{A brief research on the UFRGS developed works in the field of Photogrammetry}

In order to evaluate the importance of Photogrammetry and RPAS (UAV) in UFRGS, a search was made in the UFRGS publications repository (LUME, 2019) and a total of 243 works were found mentioning the word "Photogrammetry" in the period between 1997 and 2018. Books, manuals and handouts that have not been produced at UFRGS have been ignored. In the first of the evaluations, the works were classified as: (a) developed within the Institute of Geosciences (IGEO), where the Cartographic Engineering course is allocated and the specific disciplines of Photogrammetry, and (b) developed in other institutes and colleges (Fig 2).

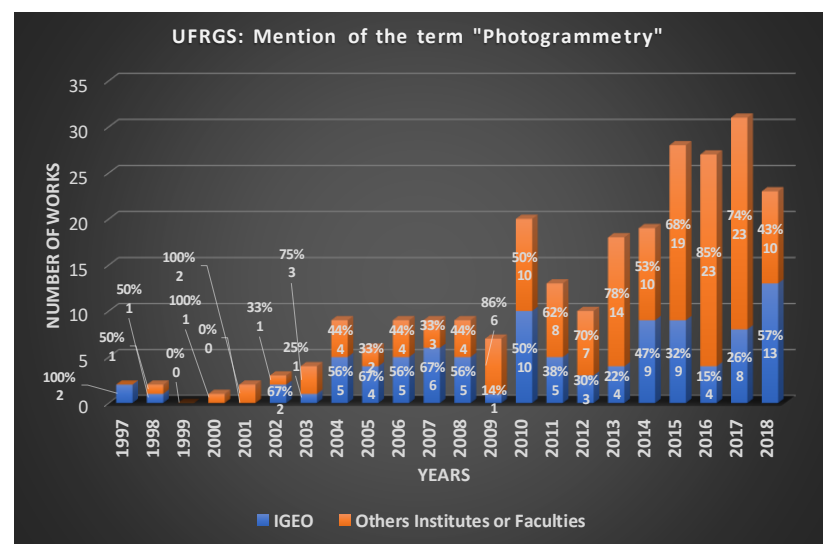

Figure 2. Mention of the word "Photogrammetry" in the works developed at UFRGS.

In all, $97(38 \%)$ of the "Photogrammetry" mentions were made in IGEO, and 155 (62\%) in other institutes and / or colleges of UFRGS. From the graph (Fig 2) it is possible to see an increase in the mention of the word in question over time, in two distinct periods: between 2004 and 2008, and again between 2010 and 2018. A second consideration was to classify the works as: (a) simple mention of the word, and (b) those that really are of development work and or application of Photogrammetry. A subdivision was made between works done in and outside IGEO (Fig 3).

By means of Figure 3 it is possible to observe that there are a smaller number of works that effectively develop or apply Photogrammetry in relation to those that only mention. Of the 97 papers that mention the term "Photogrammetry" in IGEO, 
$34 \%$ are works that develop or apply. Outside the IGEO this number is $26 \%$. Considering the entire UFRGS, this figure is $38 \%$.

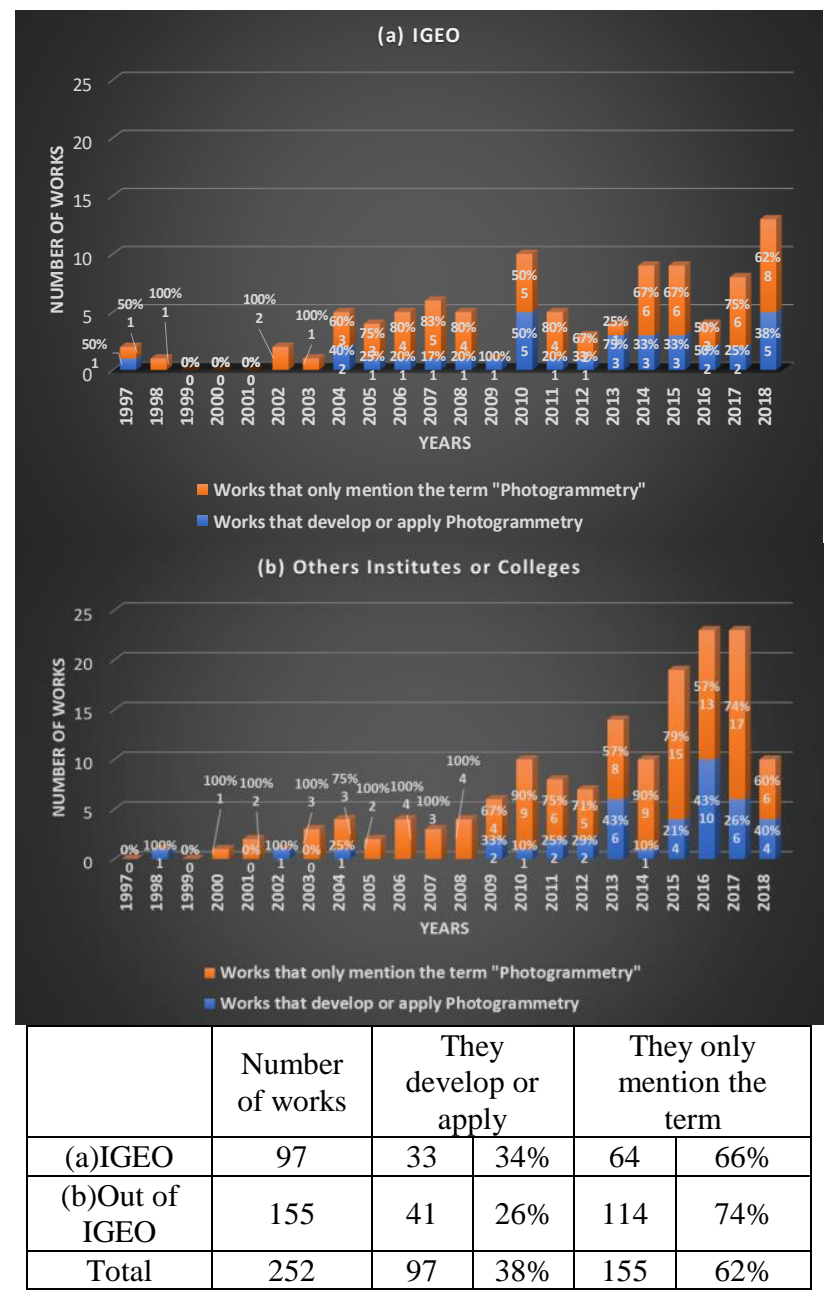

Figure 3. Works that effectively develop or apply

Photogrammetry compared to those that only mention the term: (a) IGEO; (b) Other institutes and colleges.

Analyzing Figure 4, it is possible to conclude that 33 studies of Photogrammetry (development and application) were developed at IGEO, of which $42 \%$ used RPAS as a data acquisition platform. Outside the IGEO, there were 41 papers, of which only 7\% used RPAS. Another important information comes from the analysis of Figure 5. Of the works developed within the IGEO in Photogrammetry, only $21 \%$ did not use RPAS.

With this, we can infer that:

- The existence of technology equipment made Photogrammetry more popular at UFRGS. In IGEO this occurs more from 2004/2005, and again from 2010;

- The RPAS were important in the development of works in Photogrammetry, with greater importance for Cartographic Engineering, occurring mainly from 2013;

- There is interest in Photogrammetry at UFRGS in areas other than Geosciences.

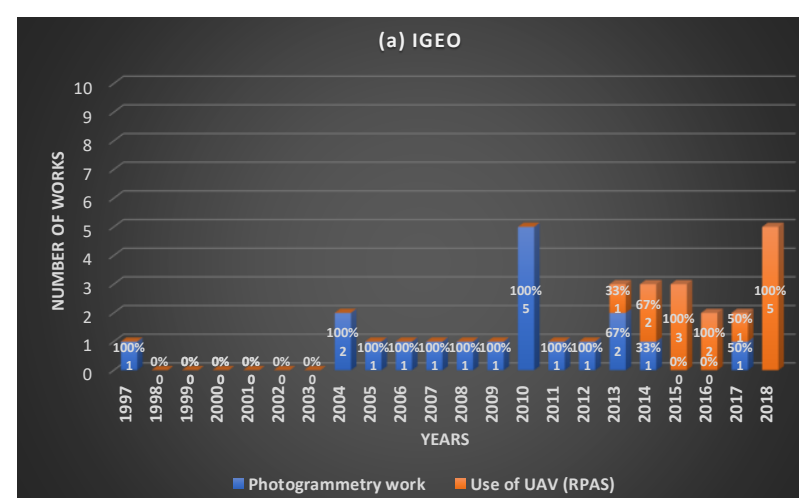

(b) Others Institutes or Faculties

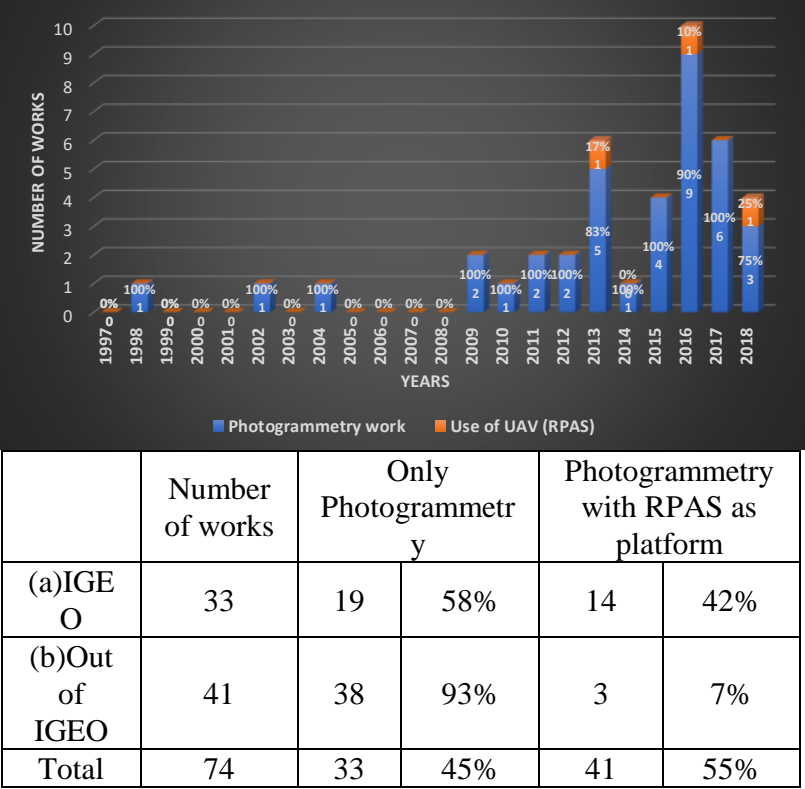

Figure 4. Works that develop or apply Photogrammetry using RPAS as one of the acquisition platforms: (a) IGEO; (b) Other institutes and Colleges.

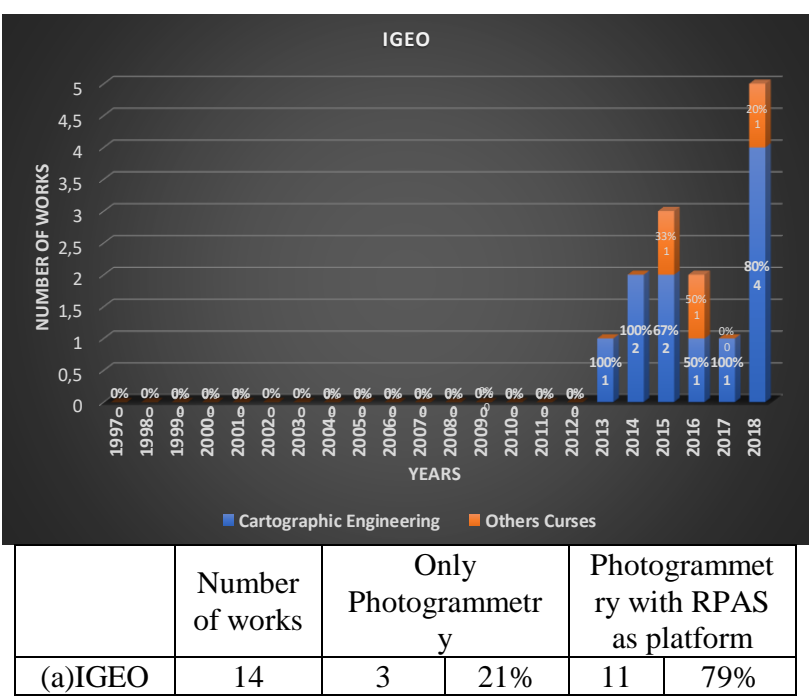

Figure 5. Works that develop or apply Photogrammetry using RPAS as one of the acquisition platforms: Cartographic

Engineering x Other Courses. 


\subsection{The teaching activities of Photogrammetry with support of the RPAS platforms}

The RPAS platforms were acquired at UFRGS through actions of LAFOTO. Since the arrival of the RPAS in UFRGS, this equipment was incorporated into the teaching activities to which they were proposed. One of the disciplines of Photogrammetry, called Introduction to Photogrammetry, which was predominantly theoretical, with laboratory-only practices, started to count on a field activity of 3 days, in which the steps of the flow described in Figure 1 were performed, as follows:

- Classroom (Digital Photogrammetry Laboratory): Planning of photo coverage and distribution of control points (step 1) (Fig 6);

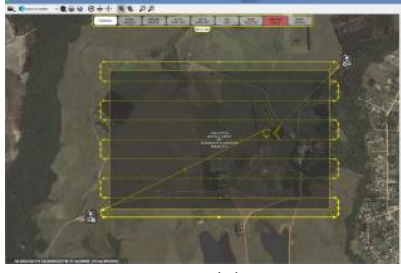

(a)
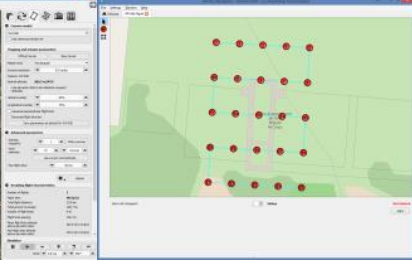

(b)
Figure 6. Photogrammetric coverage plan: (a) eBee (fixed wings); (b) Falcon 8 (rotary wings).

- In the field (in the Agronomic Experimental Station (EEA) of UFRGS, a 3600-hectare farm belonging to the University): Distribution of the pre-signalized control points (step 2) and the execution of the Photogrammetric coverage (step 3) (Fig 7);

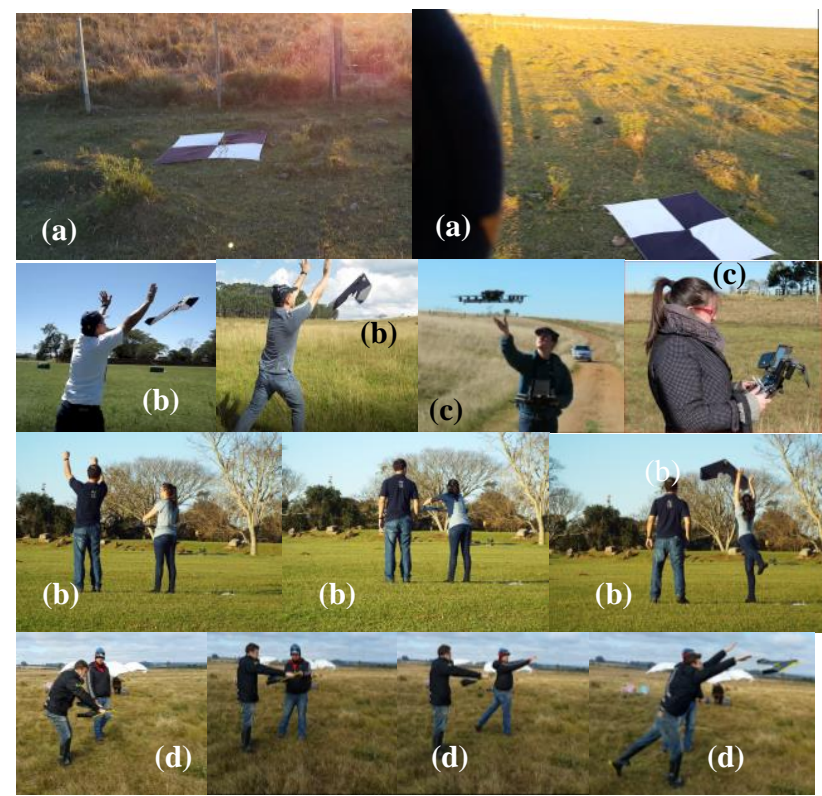

Figure 7. Distribution of pre-signaling of control points and photogrammetric flight; with the Professor teaching students: (a) Pre-signalized control points; (b) Swinglet CAM Sensefly RPAS; (c) AscTec Falcon 8 RPAS; (d) Sensefly eBee RPAS.

- In the classroom (still in the EEA), after the flight: A pre-processing of the images, with the selection of identifiable points in the photographs to be measured as control points and check point in the field (step 4) (Fig 8);

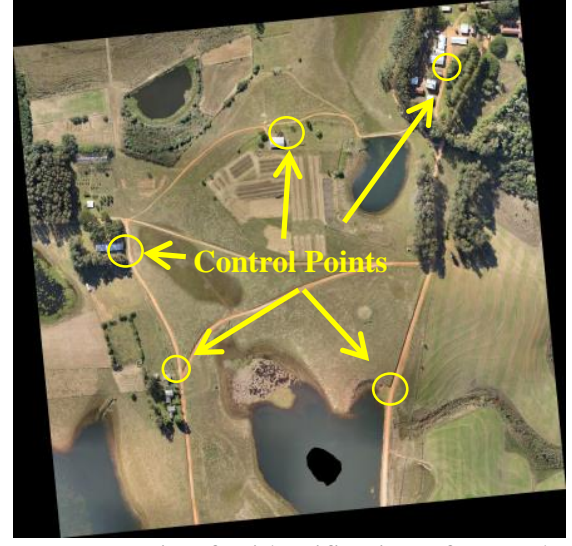

Figure 8. Pre-processing for identification of control points and check points.

- In the field (EEA): Measurement of control points by GNSS (step 5) (Fig 8);

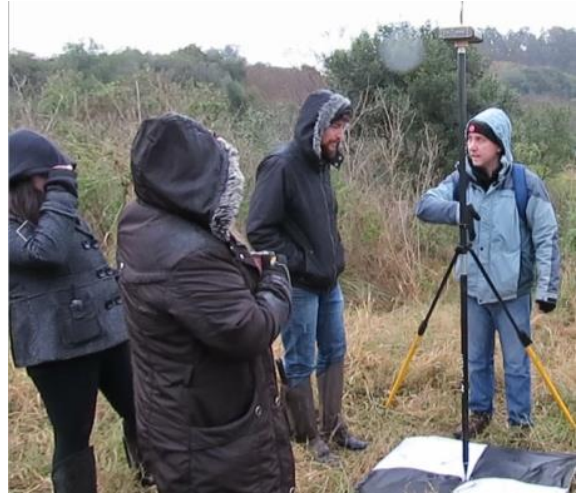

Figure 8. Professor teaching students to survey pre-signalized control points.

- In the Classroom (Digital Photogrammetry Laboratory): Processing of data acquired in the field (from step 6 onwards).

In this processing, the students perform the activities between 6 to 13 of the photogrammetric process flow, described in Figure. 1.

Currently, these described activities are being incorporated into a new discipline, which will be called: Photogrammetric Survey, in which students will continue to execute the entire flow of the photogrammetric process. In this discipline, 15 hours will be made available for lab activities and 45 hours will be for field activities. The previous discipline, Introduction to Photogrammetry, will return to be of a theoretical nature.

In addition to the use of RPAS in disciplines, 11 academic works were developed in the area of Photogrammetry as end of coursework. Below we will describe 2 of the most relevant, the first one completed, and the last one that is in progress.

\subsection{The first work of Photogrammetry with RPAS platform of UFRGS}

The first work of Photogrammetry in which RPAS was used as a platform for acquiring vertical photographs was named: Integration of Aerial Photogrammetric survey with the use of $U A V$ and terrestrial photogrammetric survey for threedimensional mapping of the ruins of São Miguel das Missões 
(In Portuguese : Integração de levantamento fotogramétrico aéreo com o uso de RPAS e levantamento fotogramétrico terrestre para o mapeamento tridimensional das ruínas de São Miguel das Missões). This work was developed by Palermo and Leite (2013) as an under-graduation end of coursework of Cartographic Engineering. The study area (Fig 9b) was the Archaeological Park of São Miguel das Missões, in the city of São Miguel das Missões, in the State of Rio Grande do Sul, Brazil. In this park are the ruins of the Church of São Miguel Arcanjo (Humanity World Heritage by UNESCO since 1983), where one of the seven village of the Brazilian Jesuit Missions was located. For the mapping of the park, in this work, the RPAS Sensefly Swinglet CAM (Fig 7b) was used, equipped with an IXUS 220HS RGB photographic camera.

To have the camera calibration of this and other future works, a calibration field was assembled on one of the walls of one of the IGEO buildings, where targets were affixed, and their coordinates were determined by Topography in a local reference system (Fig 9a).

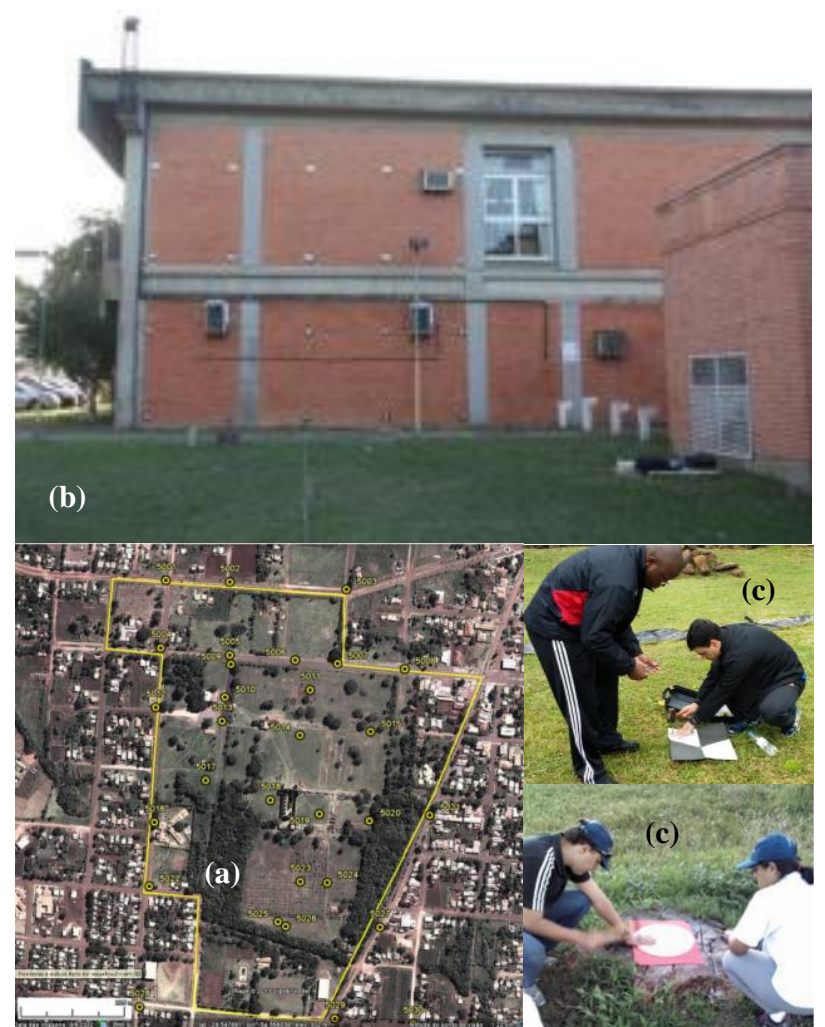

Figure 9. (a) Area of study and planning of the distribution of pre-signalized control points; (b) IGEO camera calibration Wall; (c) Pre-signaling planned control points.

Following the flow of the photogrammetric process (Fig 1), the support points to be pre-signalized on the ground (Fig 9a) and distributed (Fig 9c), and photogrammetric coverage for the area were planned. Then, considering an average pixel in the terrain of $7 \mathrm{~cm}$, the flight was performed to acquire the vertical photographs, according to the coverage plane (Fig 10a and 10b), and subsequently measured the control points (Fig 10c).

Once the control points were in the images, the phototriangulation was performed using the Agisoft Photoscan software. (a)

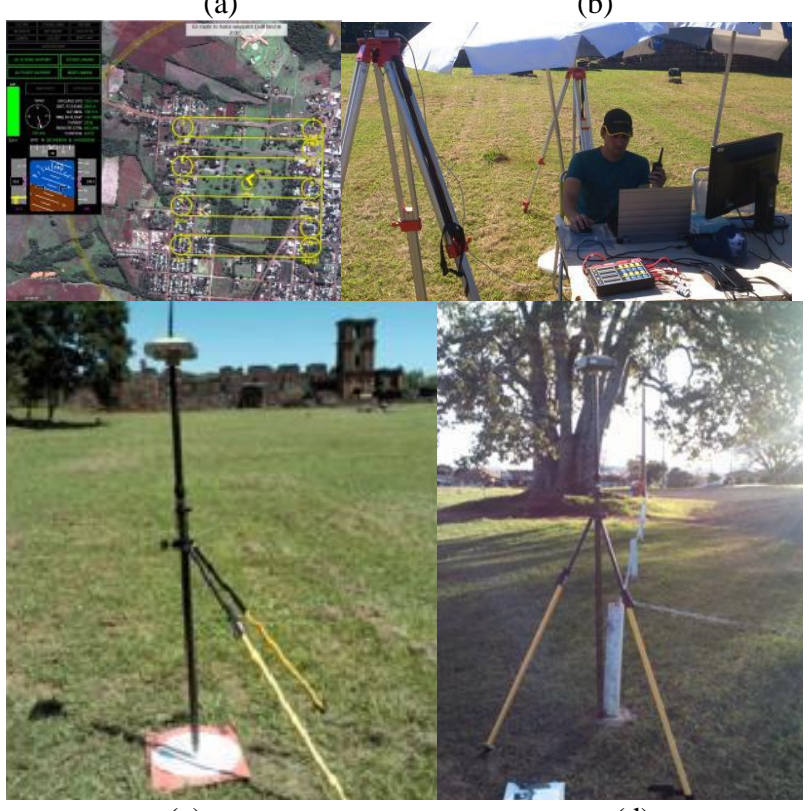

(c)

(d)

Figure 10. (a) Flight plan and control software; (b) Flight control station; (c) Control points measurement; (d) Check points measurement.

The external orientation parameters and the images were then imported into the LPS software, where the feature extraction procedure was performed with the aid of stereoscopic vision. The result of this process was the construction of the topographic map of the area of the Archaeological Park (Fig $11)$.

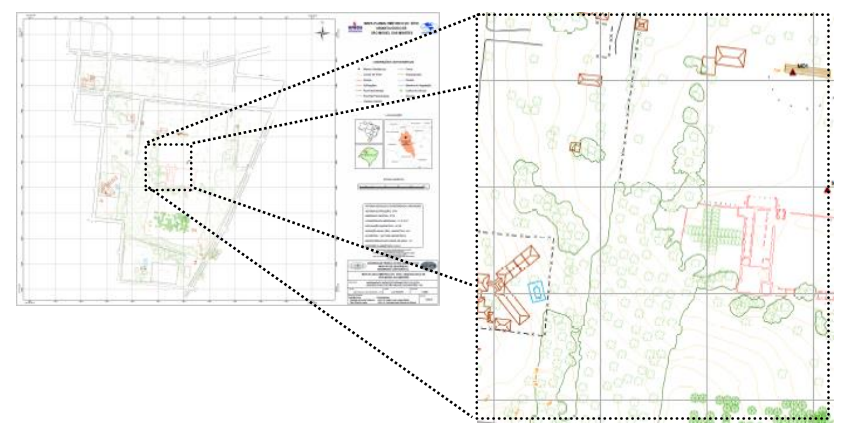

Figure 11. Map of the Archaeological Park of São Miguel das Missões-RS, Brazil, produced by Photogrammetry with RPAS.

The positional quality of the map produced (Fig 11) was better than $0.33 \mathrm{~cm} \mathrm{XY,} \mathrm{considering} \mathrm{an} \mathrm{average} \mathrm{pixel} \mathrm{of} 7 \mathrm{~cm}$ : a value of 5 pixels, considered high by the experience that was acquired later with other works. The students did not evaluate the altimetric quality. However, in terms of procedural experience, students had the possibility of contact with all stages of the photogrammetric process, partly achieving expectations. This work gave rise to a project, with a partnership between UFRGS/IGEO/LAFOTO and the National Historical Heritage Institute (IPHAN), through the regional office of Rio Grande do Sul - Brazil. In this project, other RPAS and other geospatial technologies were used: RPAS Sensefly eBee, AscTec Falcon 8, Faro Focus 3D S Laser Scanner, Optec ILRHS HD, GNSSs and Total Stations (Reiss et al, 2016, Ferraz et al, 2018). Using the integration of all these data, besides a new map, it was possible to construct the virtual 3D model of the Church of São Miguel Arcanjo (Fig. 12) (Reiss et al, 2016). 


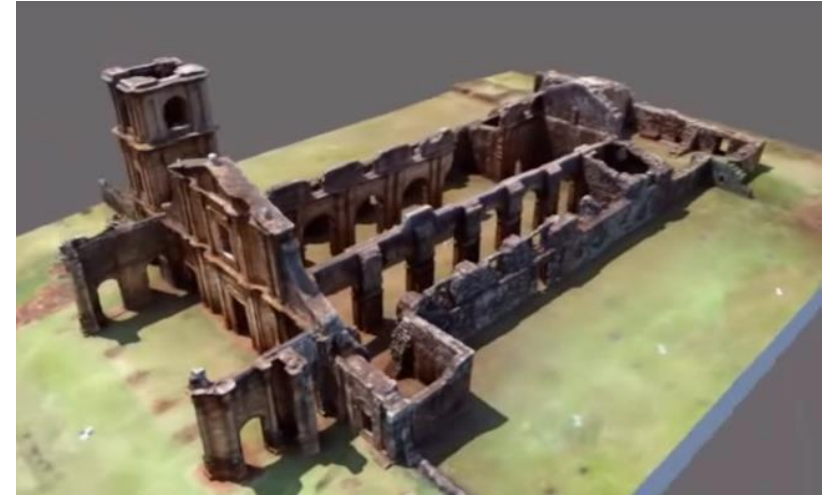

Figure 12. Fusion of 3D models produced by Photogrammetry and TLS (Reiss et al, 2016).

\subsection{Natural disaster risk assessment}

Figure 13 shows the occurrence of shallow landslides and the destruction of housing. In this place there is a history of landslides, among the most significant was the meteorological event of November 2008, which reached the Itajaí Valley. Blumenau was the second municipality that suffered the most, with 24 deaths for a total of 135 .

This study area being evaluated is Morro do Coripós, in Blumenau, State of Santa Catarina, Brazil. Many geotechnical and geophysical information were generated for Morro do Coripós after the reported event (Geoprospec, 2011).

\section{(a) (b)}

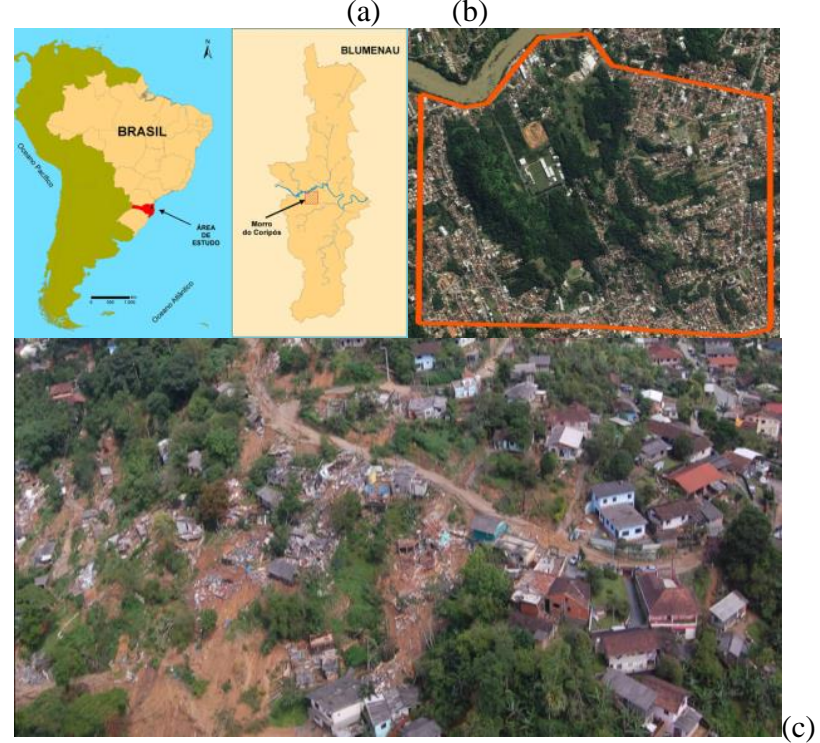

Figure 13. Study Area: (a) location Map; (b) Image adapted from Google Earth (2018); (c) Delisation occurred at 2008

(Geoprospec, 2011).

The RPAS technology has been used in several applications within the study and monitoring of risk areas of natural disasters (Lucieer et al., 2014; Turner et al., 2015). National Center for Monitoring and Early Warning of Natural Disasters (CEMADEN), related to the Ministry of Science and Technology, Innovations and Communications, was created in 2011 with the mission of carrying out continuous monitoring of areas of eminent risk in Brazil. Natural disasters, such as landslides and floods. The city of Blumenau-SC has risk areas that demand constant monitoring. The Coordination of Improvement of Higher-Level Personnel (CAPES), through a project called Pró-Alertas, funds a project involving the
Pontifical Catholic University of Rio Grande do Sul - Brazil, UFRGS and CEMADEN for the development of methodologies for monitoring risk areas through RPAS technology (Reiss et al, 2018). The main products to aid in sliding simulations are the Digital Terrain (DTM) and Elevations (DEM) Model. These two, together with geotechnical data, make it possible to calculate the stability of critical slope sites and generate a 3D immersed model to allow data integration, visualization and understanding of the sliding process in order to support decision making. For the generation of the DTM and DEM of the area, the RPAS equipment used was Sensefly eBee, equipped with a Canon PowerShot Elph 110 HS camera (Fig 7d). The survey procedures were like those performed in section 2.3 and described in the flow of Figure 1. The average pixel size in the terrain was defined as $8 \mathrm{~cm}$. The digital surface models (DSM) generated will be used in the water load simulations for the prediction of slip. An DSM can be seen in Figure 14.

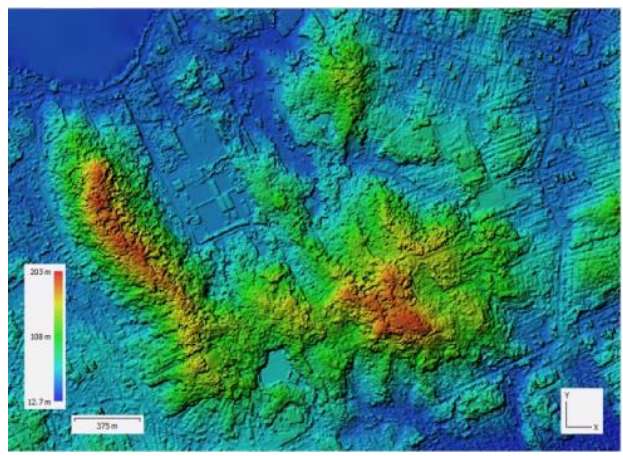

Figure 14. DEM generated to give birth of photos acquired with RPAs eBee.

This is still an ongoing project, with more information can be found in Reiss et al (2018).

\section{CONCLUSIONS}

This work can be divided into three parts, being that: the first one evaluated briefly the importance of Photogrammetry and Photogrammetry with RPAS in UFRGS, IGEO and Cartographic Engineering; in the second, it was shown how the RPAS were incorporated into the teaching activities of Cartographic Engineering students; in the third there was a brief description of two applied works of Photogrammetry with RPAS, as a way to show the applicability of these platforms.

The first of the conclusions that can be reached is that Photogrammetry has become increasingly popular as a line of research throughout UFRGS, mainly because of the advancement of technologies. Future research should aim to find out what technologies these are in other sectors of the University. In Cartographic Engineering advancement is more evident, from the availability of the RPAS from 2013, but also from other technological equipment at the same time, from 2010. It is possible to conclude that Photogrammetry is not restricted to IGEO and Cartographic Engineering. But it is important to investigate, in other institutes and colleges, how Photogrammetry is treated in terms of teaching, since they do not have specific disciplines that provide theoretical and practical support for developing Photogrammetry in applications. In the case of Cartographic Engineering, the RPAS provided the development of practical activities, with real data and experiences in the field, that would not be possible if they did not exist and were not available. But software is a differential in photogrammetric operations with RPAS, without which they are not possible to be used, and that should be 
studied in other future works, such as the one done by Coelho (2015). Finally, the existence of the RPAS in the teaching provided practical experiences to the students, in all the stages of the flow of the photogrammetric process, that were not possible in their totality previously. We attribute to the RPAS the fact that more and more students are looking for Photogrammetry as a theme for teaching and research activities.

\section{ACKNOWLEDGEMENTS}

The team thanks: to IPHAN-RS through the Cooperation Term 01/2013 UFRGS/IPHAN-RS; to CAPES by funding of the ProAlerts project (88887.091734/2014-01); to the REUNI project of the Federal Government, which provided the acquisition of part of the equipment used in the work; to UFRGS By Equipment and physical space Transferred to accomplish this work.

\section{REFERENCES}

Coelho, I. A. 2015. Avaliação da qualidade posicional de dados oriundos de VANT para mapeamento fotogramétrico aplicado em projetos rodoviários. Trabalho de Conclusão de Curso. Porto Alegre: Universidade Federal do Rio Grande do Sul (UFRGS), (2015). [392 f.] il.

Lima, E. M. de; Thomaz, T. A. M.; Severo, T. C., 2010. Mapeamento aerofotogramétrico digital utilizando fotografias de médio formato. Trabalho de Conclusão de Curso. Porto Alegre: Universidade Federal do Rio Grande do Sul (UFRGS), (2010). [126 f.] il.

Lume, 2019. Repositório Digital. https://lume.ufrgs.br/discover (02 Jan 2019).

10 Anos do Curso de Engenharia Cartográfica da UFRGS, 2018. Editores Sérgio Florêncio de Souza; Marcelo Tomio Matsuoka. - Porto Alegre: UFRGS/ IG/LPG, (2008). (Série em Geomática), v.2. 123 p.. il.

Ferraz, R. S.; Souza, S. F. ; Reiss, M. L. L., 2016. Laser Scanner Terrestre: teoria, aplicações e prática. REVISTA BRASILEIRA DE GEOMÁTICA, v. 4, p. 106-116.

Geoprospec, 2011. Relatório Geológico-Geofísico - Maciço do Morro do Coripós, Blumenau-SC. Relatório técnico. 10p. 7 mapas.

GOOGLE, 2018. Google Earth Pro. Version 7.1. Nota (Maciço do Morro do Coripós, Blumenau-SC). Disponível em: <http://www.google.com/intl/pt-BR/earth/download/gep/agree. html>. Acesso em 02/07/2018.

Klein, I.; Götz, J. J.; Rocha, L. S. S., 2009. Mapeamento Fotogramétrico Utilizando Imagens Digitais de Pequeno Formato: Área Teste Entre os Municípios de Novo Hamburgo e São Leopoldo - RS. Porto Alegre. (Trabalho de conclusão de curso). Instituto de Geociências, Universidade Federal do Rio Grande do Sul, UFRGS.

Lucieer, A.; Jong, S. M.; Turner, D., 2014. Mapping landslide displacements using Structure from Motion (SfM) and image correlation of multi-temporal UAV photography. Progress in Physical Geography, V. 38, N. 1, p. 97-116.

Palermo, R. A.; Leite, T. C., 2013. Integração de levantamento fotogramétrico aéreo com o uso de RPAS e levantamento fotogramétrico terrestre para o mapeamento tridimensional das ruínas de São Miguel das Missões. - Porto Alegre: IGEO/UFRGS

Reiss, M. L. L.; Mendes, T. S. G.; Andrade, M. R. M.; Mendes, R. M. 2018. Mapeamento fotogramétrico com uso de RPAS para a avaliação de áreas de risco geológico na cidade de Blumenau-SC In Anais do VII SIMGEO: Mapeamento da Superfície Terrestre / Estado da Arte VII Simpósio Brasileiro de Ciências Geodésicas e Tecnologias da Geoinformação RecifePE 20181 1045-1053 Recife-PE: Editora UFPE

Reiss, M. L. L.; Rocha, R. S.; Ferraz, R. S. ; Cruz, V. C. ; Morador, L. Q. ; Yamawaki, M. K. ; Rodrigues, E. L. S. ; Cole, J. O. ; Mezzomo, W., 2016. Data Integration Acquired from Micro-UAV And Terrestrial Laser Scanner for the 3d Mapping of Jesuit Ruins of São Miguel das Missões. ISPRS International Archives of the Photogrammetry, Remote Sensing and Spatial Information Sciences, v. XLI-B5, p. 315-321, 2016.

Reiss, M. L. L.; Tommaselli, A. M. G., 2011. A low-cost 3d reconstruction system using a single-shot projection of a pattern matrix. Photogrammetric Record, p. no-no, 2011.

Reiss, M. L. L.; Tommaselli, A. M. G.; Ruy, R. da S., 2009. Calibration of two cameras and a projector of structured light for mobile applications. In: 6th International Symposium on Mobile Mapping Technology, 2009, Presidente Prudente. Proceedings of the 6th ISMMT. Presidente Prudente: Unesp, 2009.

Reiss, M. L. L.; Tommaselli, A. M. G., 2018. Calibração dos sistemas de lentes de um projetor de padrões e das câmaras fotográficas de um sistema reconstrução 3D por luz estruturada. In: SAPGU2018 p. 36-41.

Ruy, R. S.; Tommaselli, A. M. G.; Galo, M. ; Hasegawa, J. K. ; Reis, T. T dos., 2012. Accuracy Analysis of Modular Aerial Digital System SAAPI in Projects of Large Areas. In: EuroCow 2012, 2012, Barcelona. EuroCow 2012, 2012.

Ruy, R. S.; Tommaselli, A. M. G.; Galo, M. ; Hasegawa, J. K. ; Reis, T. T dos; Silva, W. A. da., 2010. Accuracy assessment of projects performed by SAAPI system. In: LARS 2010, 2010 , Santiago - Chile. LARS 2010 proceedings, 2010.

Ruy, R. S.; Tommaselli, A. M. G.; Reis, T. T. dos; Galo, M.; H., J. K.; Imai, N. N; Camargo, P. de O; Magna Junior, 2007. Sistema aerotransportado leve de aquisição de imagens digitais - SAAPI. In: XIII Simpósio Brasileiro de Sensoriamento Remoto, 2007, Florianópolis. XIII Simpósio Brasileiro de Sensoriamento Remoto, 2007.

Turner, D.; Lucieer, A.; Jong, S. M., 2015. Time Series Analysis of Landslides using an Unmanned Aerial Vehicle (UAV). Remote Sensing, V. 7, p. 1736-1757, 2015.

Zanardi, R. P. ; Schneider, A. H. ; Salomoni, C. S. S. ; Mallmann, D. S. ; Salomoni, T. R. ; Reiss, M. L. L. ; Rocha, R. S. ; Iescheck, A. L. ; Tavares, M. M. ; Peixoto, E. B. A. ; Tavora, F. C. ; Martinski, P. ; Skroch, J., 2014. Análise da qualidade dos modelos digitais de terreno e de superfície do município de Porto Alegre. In: Congresso Brasileiro de Cartografia, 2014, Gramado. Anais. Rio de Janeiro: Sociedade Brasileira de Cartografia, 2014. p. 3-4.

Zanardi, R. P.; Schneider, A. H.; Salomoni, T. R.; Salomoni, C. S. S. ; Reiss, M. L. L., 2013. Validação da qualidade do perfilamento a LASER aerotransportado da cidade Porto Alegre. In: Simpósio Brasileiro de Sensoriamento Remoto, 2013, Foz do Iguaçú. Anais. São José dos Campos: MCT/INPE, 2013. p. 6178-6184. 